\title{
VIDEO YOUTUBE DALAM PENGAJARAN BASIC LISTENING
}

\author{
Rinny Rorimpandey \\ Jurusan Bahasa Inggris, Fakultas Bahasa dan Seni, \\ Universitas Negeri Manado \\ rinnyrorimpandey@unima.ac.id
}

\begin{abstract}
Abstrak
Penelitian ini bertujuan untuk mengetahui keefektifan penggunaan video Youtube terhadap pemahaman dalam listening(menyimak) pada matakuliah Basic Listening semester 1 Jurusan Bahasa Inggris.

Youtube dapatlah menjadi sarana belajar dan media pembelajaran yang dapat memenuhi tuntutan kebutuhan pelajar. Ada banyak jenis video dengan berbagai macam topik yang unik, menarik dan menyenangkan untuk dinikmati dan yang dapat digunakan dalam pelajaran di kelas.

Jenis Penelitian ini adalah quasi eksperimen dengan desain penelitian eksperimen Pretest dan Post-test Control group. Penelitian ini dilakukan di Jurusan Bahasa Inggris FBS Unima Tondano. Populasi Penelitian adalah seluruh semester 1 yang berjumlah 250 mahasiswa. Pengambilan sampel menggunakan random sampling.

Dari hasil perhitungan menunjukan nilai rata-rata kelas eksperimen sebesar 69,032 kemudian menjadi 80,403. Hal ini berarti bahwa di kelas eksperimen terjadi peningakatan sebesar 11,37. Untuk kelompok kontrol pada saat pretest sebesar 69,141 dan pada saat post-test sebesar 73,828. berarti terjadi kenaikan sebesar 4,69. Meskipun kedua kelas sama-sama mengalami kenaikan rata-rata, namun kenaikan rata-rata posttest pada kelas eksprimen lebih besar dibandingkan post-test kelas kontrol dan bobot keefektifan sebesar 9,5\%. Kesimpulannya adalah nilai pemahaman listening pada matakuliah Basic Listening lebih tinggi dengan yang menggunakan video youtube dibandingkan dengan menggunakan media konvensional. Sehingga dapat dikatakan terdapat perbedaan yang signifikan pemahaman listening mahasiswa Jurusan Pendidik Bahasa Inggris antara yang diajar dengan media video dan yang diajar dengan menggunakan media konvensional.
\end{abstract}




\section{PENDAHULUAN}

Saat ini bahasa Inggris telah digunakan sebagai alat komunikasi antar bangsa dan bahasa inggris berfungsi sebagai bahasa internasional. Bahkan ada beberapa bangsa/negara telah menggunakan bahasa ini sebagai bahasa keduanya. Bahasa inggris pun sangat berperan dalam bidang komunikasi, perdagangan, ekonomi, politik, pariwisata, pendidikan, pengetahuan dan lain sebagainya.

Walaupun di Indonesia, bahasa Inggris belum ditetapkan sebagai bahasa kedua namun bahasa Inggris sudah merupakan salah satu dari bahasa asing yang ada. Saat ini Bahasa inggris adalah sebagai bahasa target yang mesti diajarkan dan dimasukkan dalam kurikulum di setiap jenjang pendidikan yang ada di Indonesia. Mulai dari tingkat sekolah dasar sampai perguruan tinggi harus mempelajari bahasa inggris.

Pentingnya bahasa inggrisnya saat ini, menuntut para pelajar untuk dapat meningkatkan kemampuan mereka dalam berbahasa Inggris. Untuk meningkatkan kemampuan dalam penguasaan bahasa Inggris pelajar, para guru hendaknya dapat mengupayakan agar supaya para pelajar dapat menguasai dan memahami tentang bahasa inggris. Karena itulah guru haruslah memiliki berbagai pengetahuan mengenai pendekatan, metode, teknik serta media yang menarik digunakan untuk pengajaran.
Para guru dapat memberikan metode, teknik ataupun media yang menarik, sebab dengan menggunakan alat bantu pengajaran yang menunjang dalam kegiatan belajar mengajar akan menjadi daya tarik para Peserta didik untuk dapat lebih mudah mempelajari, memahami bahkan menyenangi bahasa Inggris.

Belajar bahasa Inggris sangatlah kompleks karena dalam bahasa ini mempunyai empat kemampuan dasar yaitu mendengar /menyimak(listening), berbicara (speaking), membaca (reading) dan menulis (writing) serta dengan tiga kemampuan tambahan yaitu kosakata(vocabulary), tatabahasa (grammar), dan pengucapan (pronounciation). Semua aspek ini penting dan harus dipelajari untuk menguasai bahasa inggris dengan baik.

Namun masih banyak mahasiswa yang belum mampu memahami kata ataupun kalimat dalam bahasa Inggris secara verbal oleh lawan bicaranya. Hal ini menunjukan bahwa ketrampilan mendengar (listening) masih kurang sebab dipengaruhi oleh keterbatasan penguasaan vocabulary. Itulah yang membuat banyak mahasiswa jurusan bahasa Inggris tidak tertarik pada matakuliah Basic Listening, mereka merasa bosan karena apa yang mereka dengar tidak sesuai dengan yang tertulis apalagi untuk menceritakan kembali apa yang telah mereka dengar. Padahal kompetensi 
mendengar dalam bahasa inggris merupakan kompetensi yang sangat penting.

Listening atau menyimak mempunyai peran penting dalam pengajaran bahasa, melalui Listening atau menyimak dapat meningkatkan ketrampilan bahasa lainnya seperti speaking dan writing. Oleh sebab itu pembelajaran listening perlu mendapatkan perhatian dari guru untuk lebih serius dalam menyediakan media yang cocok dan menghasilkan latihan yang lebih tepat. Media yang bisa digunakan dalam pengajaran Listening atau menyimak haruslah disesuaikan dengan perencanaan, metode dan strategi dari pengajar itu sendiri dalam proses belajar-mengajar, sebab tujuan dari penggunaan media supaya pembelajaran itu lebih mudah dimengerti oleh peserta didik sehingga terjadi proses belajar yang efisien dan efektif, sehingga tujuan pembelajaran dapat dicapai.

Dengan kemajuan teknologi diera globalisasi ini banyak tawaran untuk dapat digunakan sebagai media dalam proses pembelajaran. Salah satu cara yang lebih modern dan efektif untuk meningkatkan kemampuan mendengar dalam bahasa Inggris dari internet yang dapat dijadikan media pembelajaran khususnya matakuliah Basic Listening yaitu video youtube. Youtube memiliki banyak sekali video-video yang dapat dimanfaatkan sebagai materi untuk pelajaran bahasa inggris yang dapat dijadikan alat pembelajaran yang efektif untuk mengembangkan kemampuan listening mahasiswa.

Pada pelaksanaan pembelajaran Matakulia Basic listening yang dilaksanakan di jurusan pendidikan bahasa Inggris masih belumlah dapat merangsang mahasiswa untuk aktif di dalam pembelajaran matakuliah basic listening dimana biasanya cara dosen memperdengarkan teks dengan menggunakan tape recorder, cara seperti ini menyebabkan siswa merasa gampang bosan dan jenuh sehingga mereka tidak mengerti dan paham dengan apa yang didengar ataupun yang mereka pelajari. Untuk itu diperlukan suatu media pembelajaran yang tepat dalam rangka tujuan pembelajaran basic listening dapat tercapai.

Oleh karenanya, berdasarkan uraian di atas penulis tertarik untuk melakukan penelitian dengan judul Video youtube dalam pengajaran basic listening pada semester 1 jurusan Pendidikan Bahasa Inggris UNIMA.

\section{RUMUSAN MASALAH}

Penelitian ini mengemukakan permasalahan "Apakah ada perbedaan prestasi belajar mahasiswa antara yang menggunakan video Youtube dan yang tidak. Dan apakah penggunaan video Youtube lebih efektif atau yang tidak menggunakannya dalam pembelajaran Basic Listening. 


\section{TUJUAN PENELITIAN}

Penelitian ini bertujuan untuk mengetahui video youtube digunakan dalam pengajaran Basic listening mahasiswa semester I. Secara khusus penelian ini bertujuan :

- untuk mengetahui keefektifan penggunaan video Youtube terhadap pemahaman dalam mendengar (listening comprehension) pada Matakulia basic Listening

- Untuk mengetahui perbedaan yang signifikan prestasi belajar Basic Listening mahasiswa semester 1 Jurusan Bahasa Inggris menggunakan video Youtube dan yang tidak.

\section{Media pembelajaran}

Azhar (2011) Media pembelajaran adalah alat bantu pada proses belajar baik di dalam maupun di luar kelas, lebih lanjut dijelaskan bahwa media pembelajaran adalah komponen sumber belajar atau wahana fisik yang mengandung materi instruksional di lingkungan siswa yang dapat merangsang siswa untuk belajar. Dan menurut Rayanda Asyar (2012:8) mengemukakan bahwa media pembelajaran dapat dipahami sebagai segala sesuatu yang dapat menyampaikan atau menyalurkan pesan dari sumber secara terencana, sehingga terjadi lingkungan belajar yang kondusif dimana penerimanya dapat melakukan proses belajar secara efisien dan efektif.. Jadi media pembelajaran adalah alat bantu proses belajar mengajar, yaitu segala sesuatu yang dapat dipergunakan untuk merangsang pikiran, perasaan, perhatian dan kemampuan atau ketrampilan pelajar sehingga dapat mendorong terjadinya proses belajar pada peserta didik. Pada dasarnya fungsi media adalah untuk memperjelas penyajian materi agar tidak membosankan dan dapat dipahami dengan mudah. Media juga harus bisa mengatasi keterbatasan daya indra dan ruang waktu agar kegiatan belajar lebih kondusif. Media juga berfungsi untuk menarik perhatian siswa dan menimbulkan gairah serta semangat belajar para peserta didik. Dengan penggunaan media, diharapkan anak bisa belajar sesuai dengan minat dan kemampuannya.

Media bisa berupa buku, kaset, film, dan lain sebagainya. Penggunaan media memang harus dipilih dengan baik agar bisa mendukung suasana dan kegiatan belajar mengajar. Memilih media pembelajaran untuk kegiatan belajar tidak boleh asalasalan. Sebab media harus memenuhi kriteria khusus agar bisa dijadikan sebagai alat untuk merangsang daya pikir dan keingintahuan siswa dalam belajar. Kriteria media untuk belajar dapat mendukung isi materi pelajaran, mudah dipahami, pengajar dapat mengaplikasikannya dan sesuai dengan kemampuan berpikir siswa.

Djamarah (2002) mengelompokkan media kedalam beberapa jenis , yaitu : 
1. Media audio yaitu media yang hanya mengandalkan kemampuan suara saja, seperti tape recorder.

2. Media visual yaitu media yang hanya mengandalkan indra penglihatan dalam wujud visual.

3. Media audiovisual yaitu media yang berupabunsur suara dan gambar yang bergerak, seperti film, video cassete dan VCD.

Media audiovisual disebut juga media video. Video merupakan media yang sekarang sedang digemari banyak orang. Menurut Anderson Ronald (1994:99) media video adalah merupakan rangkaian gambar elektronik yang disertai dengan unsur suara dan unsur gambar.

\section{Video Youtube sebagai media belajar}

Seiring dengan perkembangan ilmu pengetahuan dan teknologi penggunaan media pendidikan ini adalah tuntutan yang mendesak. Video merupakan serangkaian gambar gerak yang disertai suara yang membentuk satuan yang dirangkai menjadi alur, dengan pesan-pesan di dalamnya untuk ketercapaian tujuan pempelajaran yang disimpan dalam proses penyimpanan dan disk (Arsyad,2020:36 ). Jadi video adalah gambar yang disertai dengan suara yang berisikan pesan untuk tujuan pembelajaran .

Youtube adalah sebuah situs website media sharing video online terbesar dan paling popular di dunia internet. Saat ini pengguna youtube terbesar diseluruh dunia dari berbagai kalangan usia, dari tingkat anaka-anak sampai dewasa. Youtube adalah situs web yang menyediakan berbagai macam video mulai dari video klip sampai film, serta video-video yang dibuat oleh pengguna youtube sendiri. Youtube adalah situs website media sharing video online terbesar dan paling populer di dunia internet saat ini. Para pengguna YouTube dapat mengupload video,serach video,menonton video sebagai media pembekajaran.

Video Youtube adalah berisikan rekaman gambar yang bergerak yang disertai suara yang dan dipilih untuk dijadikan sebagai media pembelajaran. Memang tidak semua video yang ada dalam youtube dapat digunakan untuk tujuan pembelajaran, oleh karena itu perlu ada perencanaan yang baik, agar video yang diambil dari Youtube adalah yang tepat sebagai sarana pendukung yang optimal dalam mencapai tujuan pembelajaran. Sehingga video youtube dapatlah menjadi sarana belajar dan media pembelajaran yang dapat memenuhi tuntutan kebutuhan generasi digital. Ada banyak jenis video dengan berbagai macam topik yang unik, menarik dan menyenangkan untuk dinikmati dan yang dapat digunakan dalam pelajaran di kelas.

Ada berbagai topik yang dibahas di kelas basic Listening, semester 1, Jurusan 
Pendidikan bahasa Inggris diantaranya, numbers (times and dates) names, receipes, Funiture and rooms dll. maka dosen harus mencari dan menyiapkan video sesuai dengan topik, dan video-video peroleh dari Youtube dipergunakan sebagai sumber pembelajaran. Ada beberapa video yang ditampilkan selama pelajaran berlansung yang disesuaikan dengan topik yang dibahas setiap minggunya. Pada awal semester mahasiswa mendapatkan silabus lengkap dengan buku referensi wajib. Setiap materi selalu ditayangkan Video yang diambil dan dipilih dari Youtube yang ditonton di kelas disesuaikan dengan pokok bahasan yang sudah direncanakan. Mahasiswa ditugaskan membaca buku referensi wajib dan mendengar serta menonton video Youtube diputar di kelas sebagai tambahan informasi, contoh kasus, dan sumber data.

Video youtube dapat dijadikan sebagai sumber belajar dan media pembelajaran yang mampu memenuhi tuntutan generasi digital, dan pula dapat meningkatkan serta minat belajar gaya belajar. Youtube menyediakan berbagai macam topic yang dapat digunakan dalam pembelajaran kelas,serta youtube dapat dijadikan perpustakaan video gratis bagi pelajar untuk belajar mandiri.Tujuan pembelajarana dengan menggunakan video youtube adalah untuk menciptakan kondisi dan suasana pembelajaran yang menarik, menyenangkan dan interaktif.
Penggunaan video youtube dalam pembelajaran bahasa Inggris dapat membuat proses belajar lebih menyenangkan, belajar cara pengucapan yang tepat dari suatu kata dalam bahasa a]Inggris, video yutube dapat membuat pemahaman materi lebih mudah dan mudah mengakses video berbagai topik .

\section{Listening dalam pembelajaran bahasa Inggris}

Listening atau menyimak adalah satu proses mendengarkan lambang lambang lisan dengan penuh perhatian, pemahaman, apresiasi untuk memperoleh informasi, menangkap isi atau pesan serta memahami makna komunikasi yang telah disampaikan oleh pembicara melalui atau bahasa lisan.(Tarigan 1999 ) Tujuan listening atau menyimak menurut Lagon (Tarigan 2008) antara lain adalah pertama, menyimak un tuk belajar, sebagian orang melakukan kegiatan menyimak agar dapat memperoleh pengetahuan dari bahan ujaran sang pembicara, kedua menyimak untuk mengevaluasi: merupakan tujuan menyimakuntuk menilai apa yang disimak. Penilaian itu baik-buruk, indah- tidak indah, tepat -tidak tepat, logis-tidak logis dan lainlain, ketiga menyimak untuk apresiasi; salah satu tujuan menyimak adalah untuk menikmati dan menghargai sesuatu yang telah disimak. Tujuan menyimak semacam ini merupakan menyimak utuk menapresiasi materi simakan. keempat 
menyimak untuk mengkomunikasikan ideide sendiri. Sebagian orang menyimak dengan maksud agar dapat mengkomunikasikan ide-ide, , gagasan maupun perasan-perasannya kepada orang lain dengan lancer dan tepat. Hal itu merupakan bahan penting sebagai penunjang dalam menyampaikan ide-idenya sendiri. Kelima untuk membedakan bunyi. Tujuanya agar dapat mebedakan bunyi dengan tepat, mengetahui bunyi yang membedakan arti dan bunyi yang tidak membedakan arti. Keenam mrnyimak untuk memecahkan masalah, itu berarti agar pendengar dapat memecahkan masalah secara kreatif dan analisi, sebab dari kegiatan menyimak dapat diperoleh banyak informasi yang berharga dan bermanfaat.

Ada dua jenis listening/menyimak yaitu menyimak secara interaktif dan non interaktif. Menyimak atau listening secara interaktif yaitu yang terjadi dalam percakapan tatap muka dan percakapan ditelepon. Sedangkan non inter aktif terjadi saat mendengarkan radio, TV,video,khotbah,dll.

Listening merupakan ketrampilan yang mendasar untuk mengembangkan ketrampilan lainnya. Karena pentingnya Listening/menyimak maka Jurusan Pendidikan bahasa Inggris, FBS, UNima menjadikannnya sebagai matakuliah yang berjenjang, dimana matakuliah ini diberikan pada tiga semseter. Semester 1 yaitu Basic listening, semseter ke 2 adalah intermediate listening dan pada semserter ketiga adalah advance listening. Dan untuk basic listening materi yang diberkan adalah hal dasar, seperti numbers, times.

\section{Penggunaan video youtube dalam} pembelajaran Basic Listening

Penggunaan video Youtube sebagai media pembelajaran bahasa inggris khususnya listening tentu bertujuan untuk membuat peserta didik terbiasa dengan bahasa inggris. Pada situs ini guru dapat mencari berbagai jenis materi pembelajaran dengan audio visual untuk dapat meningkatkan kemampuan Listening mahasiswa.

Kegiatan yang dilakukan dalam pembelajaran Basic Listenig dengan menggunakan video youtube:

Sebelum diputar Video Youtube tersebut guru menjelaskan topik, serta tujuan dari topik tersebut. Dalam pemutaran Video Youtube terebut pengajar/dosen hanyalah mendampingi mahasiswa, dan lebih bisa berperan sebagai fasilitator. Selain menyediakan video harus pun dilengkapi dengan materi, video pembelajaran juga dilengkapi dengan soal evaluasi, kunci jawaban, dan lain sebagainya sesuai dengan kreatifitas yang membuatnya.

Setelah video youtube dan materi serta fasilitas yang dibutuhkan sudah tersedia maka guru memutar sebanyak dua kali video youtebe yang sesuai dengan topik pembahasan, dan menganjurkan mereka 
untuk memahami apa yang dilihat dan didengarnya. Sekali lagi memutar video tersebut namun tidak memperlihatkan gambar dari video tapi hanyalah suaranya yang didengar. Kemudian pengajar/dosen dapat menghentikan sebentar video untuk diskusi singkat atau pertanyaan-pertanyaan seputar isi video. Mahasiswa diberi tugas untuk mencatat pokok-pokok informasi yang ada dalam tayangan video youtube.

Selanjutnnya mahasiswa berlatih saling menyampaikan informasi bersama temannya dengan memperhatikan kecepatan intonasi, kejelasan lafal, kelancaran ucapan, kesesuaian isi informasi, pilihan kata, tatabahasa dan kewajaran ekspresi. Kemudian mahasiswa satu persatu latihan menyampaikan atau menceritakan kembali apa yang ditonton dan di dengarnya.

\section{METODE PENELITIAN}

Desain Penelitian

Penelitian ini merupakan penelitian kuantitatif dengan menggunakan metode quasi experiment atau eksperimen semu. Dalam penelitian ini dibutuhkan dua kelas untuk diteliti, yaitu kelas eksperimen yang diberi perlakuan pembelajaran dengan menggunakan media video animasi dan kelas kontrol yang menggunakan media konvensional. Desain penelitian yang digunakan adalah Pre-test Post-test Control Group Design. Menurut Sukardi (2003:
186), desain penelitian dapat digambarkan sebagai berikut. Desain Penelitian

Desain penelitian:

\begin{tabular}{|l|c|c|c|}
\hline Group & Pretest & Treatment & Posttest \\
\hline Eksperimental & $\mathrm{Y} 1$ & $\mathrm{X}$ & $\mathrm{Y} 2$ \\
\hline Control & $\mathrm{Y} 1$ & $\mathrm{X}$ & $\mathrm{Y} 2$ \\
\hline
\end{tabular}

Keterangan :

Y1 : Pre-test

Y2 : Post-test

$\mathrm{X}$ : Perlakuan dengan media video animasi Variabel Penelitian

Dalam penelitian ini terdapat dua variabel yang digunakan, yaitu variabel terikat dan variabel bebas. Variabel terikat yaitu pemahaman listening bahasa Inggris mahasiswa semeter 1 jurusan Pendidikan Bahasa Inggris FBS Unimal. Variabel bebas yaitu penggunaan video yuotube dalam pembelajaran Basic Listening.

Subjek Penelitian

1. Populasi Penelitian

Populasi adalah seluruh data yang menjadi perhatian kita dalam suatu ruang lingkup dan waktu yang kita tentukan (Margono, 2010: 18). Populasi dalam penelitian ini adalah. mahasiswa semeter 1 jurusan Pendidikan Bahasa Inggris FBS Unimal. tahun ajaran 2018/2019 yang seluruhnya berjumlah 150 mahasiswa, yang terdiri dari 5 kelas yaitu A, B, C, D, E

\section{Sampel Penelitian}

Sampel adalah sebagai bagian dari populasi, sebagai contoh (peserta didik) yang diambil dengan menggunakan caracara tertentu (Margono, 2010: 121). Teknik pengambilan sampel dalam penelitian ini 
menggunakan teknik simple random sampling yaitu pengambilan sampel secara acak sederhana yang dilaksanakan dengan cara diundi seluruh anggota populasi yang mempunyai kesempatan untuk menjadi sampel penelitian (Sukardi, 2003: 58). Teknik pengambilan sampel dapat dilakukan melalui undian, ordinal, atau menggunakan tabel bilangan random. Teknik pengambilan sampel dalam penelitian ini menggunakan undian. Teknik ini digunakan untuk mengambil kelas yang dijadikan sampel penelitian dari keseluruhan kelas yang dipopulasikan. Langkah-langkah pengambilan sampel adalah sebagai berikut. (1) Menentukan populasi yang akan diteliti. (2) Menempatkan kelas-kelas yang menjadi populasi ke dalam kotak yang telah diberi lubang di atasnya. (3) Mengocok kotak tersebut. (4) Kertas yang keluar pertama dijadikan kelas eksperimen, sedangkan kertas yang keluar kedua dijadikan kelas kontrol. Berdasarkan hasil pengambilan sampel, maka diperoleh kelas A (31 mahasiswa) sebagai kelas eksperimen dan kelas D 2 (32 mahasiswa sebagai kelas kontrol.

Teknik Pengumpulan Data

Teknik pengumpulan data merupakan langkah yang paling utama dalam penelitian, karena tujuan utama dari penelitian adalah mendapatkan data. Tanpa mengetahui teknik pengumpulan data, maka peneliti tidak akan mendapatkan data yang memenuhi standar data yang ditetapkan (Sugiyono, 2012: 308). Teknik

Teknik Pengumpulan Data

Teknik pengumpulan data merupakan langkah yang paling utama dalam penelitian, karena tujuan utama dari penelitian adalah mendapatkan data. Tanpa mengetahui teknik pengumpulan data, maka peneliti tidak akan mendapatkan data yang memenuhi standar data yang ditetapkan (Sugiyono, 2012: 308). Teknik Teknik pengambilan data yang digunakan dalam penelitian ini adalah tes awal (pretest) dan tes akhir (post-test) pemahaman listening pada matakuliah basic listening . Tes awal dilakukan untuk mengetahui kemampuan pemahaman listening mahasiswa ebelum diberikan perlakuan dan test akhir untuk mengetahui kemampuan pemahaman listening pada matakuliah basic listening mahasiswa setelah adanya perlakuan.

\section{F. Insrtrumen Penelitian}

Jenis instrumen penelitian dalam penelitian ini adalah tes Listening dalam bentuk soal pilihan ganda yang terdiri dari opsi a, b, c, dan d. Selanjutnya bentuk soal dengan jawaban yes or no (ya atau tidak). Soal listening ini berbentuk wacana lisan dan dipedengarkan melalui laptop dan speaker aktif. Instrumen tes dibuat sendiri oleh peneliti berdasarkan silabus yang digunakan sebagai pedoman pembelajaran basic Listening di jurusan Pendidikan bahasa Inggris, Unima. Di dalam silabus 
disebutkan bahwa dalam pembelajaran basic Listening mahasiswa diharapkan dapat memperoleh informasi umum, informasi tertentu, serta secara rinci dengan materi pokok dari buku Listen Carefully berupa numbers, names, meeting people. Recipes. Untuk penilaian tes dilakukan dengan cara memberi skor satu (1) untuk jawaban yang benar dan nol (0) untuk jawaban yang salah (Nurgiyantoro 2010).

\section{HASIL DAN PEMBAHASAN}

Hasil Penelitian

Penelitian ini bertujuan untuk mengetahui perbedaan yang signifikan pemahaman listening mahasiswa Jurusan Pendidikan Bahasa Inggris semester 2 antara yang diajar dengan menggunakan video youtube dan yang diajar dengan menggunakan media konvensional. Selain itu juga bertujuan untuk mengetahui keefektifan penggunaan video youtube dalam matakuliah Basic Listening.

1. Deskripsi Data Pre-test Kelas Eksperimen dan Kelas Kontrol

a. Data Pre-test Kelas Eksperimen

Dari hasil perhitungan nilai pemahaman listening pada Basic Listening kelas eksperimen pada saat pre-test diperoleh nilai terendah 60,00 dan nilai tertinggi 80 . Selanjutnya dengan bantuan SPSS 17 dapat diketahui bahwa nilai rata-rata (mean)sebesar 69,03, nilai tengah (modus) sebesar 60,00, dan simpangan baku (standar deviasi) sebesar 6,44.

b. Data Pre-test Kelas Kontrol

Dari hasil perhitungan nilai pemahaman listening pada matakuliah basic listening mahasiswa kelas kontrol pada saat pre-test diperoleh nilai terendah 50 dan nilai tertinggi 80. Selanjutnya dengan bantuan SPSS 17 dapat diketahui bahwa nilai ratarata (mean) sebesar 69,03, nilai tengah (modus) sebesar 72,50, dan simpangan baku (standar deviasi) sebesar 7,741.

2. Deskripsi Data Post-test Kelas Eksperimen dan Kelas Kontrol

a. Data Post-test Kelas Eksperimen

Skor pemahaman listening pada basic listening mahasiswa kelas eksperimen pada saat post-test diperoleh nilai terendah 67,5 dan nilai tertinggi 90,2 Selanjutnya dengan bantuan SPSS 17 dapat diketahui bahwa nilai rata-rata (mean) sebesar 80,4 , nilai tengah (median ) sebesar 80,00, dan simpangan baku (standar deviasi) sebesar $6,7$.

b. Data Post-test Kelas Kontrol Pemahaman listening pada matakuliah Basic Llistening mahasiswa yang diajar dengan media video pada saat post-test paling banyak berada pada interval 86,5 90,2 dan 78,9 - 82,6 dengan nilai yang sering muncul adalah 77,50

2. Pembahasan

Terdapat perbedaan yang signifikan pemahaman listening pada matakulia Basic Listening mahasiswa Jurusan Pendidik 
Bahasa inggris semester 1 antara yang diajar dengan menggunakan video youtube dan yang diajar dengan menggunakan media konvensional.

Tujuan penelitian ini untuk mengetahui adanya perbedaan Pemahaman listening pada Matakuliah Basic Listening mahasiswa Jurusan Pendidik Bahasa inggris semester 1 antara yang diajar dengan menggunakan video youtube dan yang diajar dengan menggunakan media konvensional. Disamping itu pula penelitian ini bertujuan untuk mengetahui keefektifan penggunaan video youtube dalam pembelajaran Basic Listening mahasiswa Jurusan Pendidik Bahasa inggris semester 1.

Bukti dari hasil pre-test dan posttest kelas kontrol dan kelas eksperimen. bahwa terdapat perbedaan yang signifikan pemahaman listening pada matakuliah basic Listening antara yang diajar dengan menggunakan video youtube dan yang diajar dengan menggunakan media konvensional.

Video youtube yang digunakan di kelas eksperimen itu sangatlah fungsional, menantang daya ingat, konsentrasi, dan yang terpenting mahasiswa dapat mengerti dan menangkap materi yang disampaikan. Pemakaian video youtube dalam pembelajaran basic Listening sangat menarik perhatian param mahasiswa karena memperlihatkan sepenggal kejadian atau peristiwa secara kronologis dan langsung sehingga mahasiswa tidak hanya membayangkan atau mengguest. Maka tentu saja penggunaan video youtube dapat menarik respon mahasiswa. Dengan beragam manfaat video youtube, maka pengguanaan video youtube sangat diperlukan dalam pembelajaran Basic Listening sehingga mahasiswa tidak merasa jenuh dan pembelajaran berlangsung tidak monoton. Hal in sejalan dengan manfaat video youtube yang dikemukakan oleh Arsyad (2010: 49-50) yaitu dapat memusatkan perhatian dan mempertahankan perhatian, dapat mengikuti pengarahan, melatih daya analisis, menentukan arti konteks, dapat memilah-milah informasi atau gagasan yang relevan dan informasi yang tidak relevan,dan dapat merangkum, mengemukakan kembali, atau mengingat kembali informasi. Dengan demikian video youtube sangat diperlukan dalam proses pembelajaran.

Video youtube yang melibatkan dua indera yaitu indera pendengaran dan penglihatan secara bersamaan sangat membantu mahasiswa dalam mencerna, dan mengolah informasi, serta berimajinasi dalam pikiran mereka. Selain itu penggunaan video youtube yang dapat membuat mahasiswa merasa tertantang, merespon lebih positif, dan lebih bergairah. Berbeda halnya dengan peserta didik yang menggunakan media konvensional, mereka cenderung mengerjakan hal lain, tidak bersemangat, dan kurang merespon 
terhadap materi bahkan mengeluh karena tidak mengerti apa yang disampaikan. Oleh karena itu video youtube dapat membantu pengajar dalam proses pembelajaran yaitu bagaimana menyampaikan informasi melalui indera penglihatan dan pendengaran. Maka pembelajaran akan berjalan tidak monoton.

Setelah pengambilan data akhir kelas eksperimen, hasil perhitungan menunjukan nilai rata-rata kelas eksperimen sebesar 69,032 kemudian menjadi 80,403 . Hal ini berarti bahwa di kelas eksperimen terjadi peningakatan sebesar 11,37. Untuk kelompok kontrol pada saat pretest sebesar 69,141 dan pada saat post-test sebesar 73,828. berarti terjadi kenaikan sebesar 4,69. Meskipun kedua kelas sama-sama mengalami kenaikan ratarata, namun kenaikan rata-rata post-test pada kelas eksprimen lebih besar dibandingkan post-test kelas kontrol. Kesimpulannya adalah nilai pemahaman listening pada matakuliah Basic Listening lebih tinggi dengan yang menggunakan video youtube dibandingkan dengan menggunakan media konvensional. Sehingga dapat dikatakan terdapat perbedaan yang signifikan pemahaman listening mahasiswa Jurusan Pendidik Bahasa inggris semester 2 antara yang diajar dengan media video dan yang diajar dengan menggunakan media konvensional.

Penggunaan video youtube dalam pembelajaran Basic Listening mahasiswa
Jurusan Pendidikan Bahasa inggris semester 1 adalah lebih efektif daripada dengan menggunakan media konvensional. Karena pembelajaran Basic Listening perlu latihan berulang-ulang, matakuliah ini memerlukan proses mendengarkan, berpikir, berkonsentrasi untuk memeperoleh informasi, untuk membiasakan diri mendengar bunyi atau istilah-istilah asing, dipahami dan sehingga membentuk informasi baru bagi mahasiswa. Dengan menggunakan youtube mahasiswa dapat belajar dan mendengar langsung native speaker berbicara dalam bahasa inggris, semakin sering mereka mendengar native speaker berbicara maka semakin mereka terbiasa dengan ucapn-ucapan itu.

Youtube merupankan media yang menarik yang dapat membantu mahasiswa dalam proses pembelajaran Basic Listening sehingga proses pembelajaran berlangsung tidak membosankan dan dapat menghilangkan anggapan mahasiswa bahwa matakuliah Basic Listening dan bahasa Inggris tidak menarik dan sulit selain itu juga video youtube dapat membantu pengajar dalam menyampaikan materi pembelajaran.

Hal lainya yang sangat diperlukan untuk menunjang kemampuan pemahaman listening pada matakuliah basic Listening diantaranya motivasi, minat dan bakat, lingkungan belajar, fasilitas perkuliahan /sekolah, serta pengajar sebagai fasilitator dan motivator dalam kelas. Ini saling 
berkaitan satu dengan yang lain maka keberhasilan pembelajaran dapat dicapai. Dengan demikian, hasil penelitian ini dapat mendukung dan membuktikan teori-teori tentang video youtube seperti yang telah diuraikan sebelumnya.

\section{KESIMPULAN DAN SARAN}

\section{Kesimpulan}

Berdasarkan hasil analisis data penelitian, maka dapat ditarik kesimpulan:

1. Terdapat perbedaan pemahaman listening yang signifikan pada matakuliah basic listening mahasiswa semeter 1 Jurusan Pendidikan Bahasa Inggris, FBS Unima antara yang diajar dengan menggunakan video youtube dan yang diajar dengan menggunakan media konvensional. Hal ini dibuktikan dengan thitung sebesar 5,606 lebih besar dari ttabel sebesar 2,000 dengan $\mathrm{df}=58$ dan $\mathrm{a}=0,05$. Jadi nilai thitung lebih besar dari ttabel (thitung $=5,606>$ ttabel $=2,000$ ) yang artinya terdapat perbedaan yang signifikan pemahaman listening dengan menggunakan video.

2. Penggunaan media video dalam pembelajaran basic listening mahasiswa semeter 1 Jurusan Pendidikan Bahasa Inggris, FBS Unima untuk pemahaman mendengar adalah lebih efektif daripada dengan menggunakan media konvensional. Hal ini dibuktikan dengan bobot keefektifan sebesar $9,5 \%$.

\section{Saran}

1. Pengajar hendaknya menggunakan media yang tepat dan penggunaannya disesuaikan dengan materi pembelajaran yang akan diajarkan pada mahasiswa.

2. Pengajar harus lebih selektif, variatif dan kreatif dalam pemilihan dan penggunaan media pembelajaran agar mahasiswa tidak cepat jenuh dan pembelajaran berlangsung tidak monoton.

\section{KEPUSTAKAAN}

Anderson Ronald H. (1994). Pemilihan dan Pengembangan Media Untuk Pembelajaran (terjemahan Yusufhafi Miarso, dkk). Jakarta: Raja Grafindo Persada

Annurrahman. 2009. Belajar dan Pembelajaran. Jakarta: Alfabet.

Arif S. Sadiman,dkk. (2011). Media Pendidikan, Pengertian, Pengembangan dan Pemanfaatannya. Jakarta : Raja Grafindo Persada

Arikunto, Suharsimi. 2002. Dasar-dasar Evaluasi Pendidikan (Edisi Revisi). Jakarta: Bumi Aksara

Asyhar, R. (2001). Kreatif Mengembangkan Media Pembelajaran. Jakarta: Gunung Persada Press

Azhar Arsyad, (2011). Media Pembelajaran. Jakarta : Rajawali Pers.

Brown, H. Douglas. 2000. Principles of Language Learning and Teaching 4th ed. San Fransisco: Pearson Education Ltd.

Jack C. Ricards, (2004). Listen Carefully. Oxford University Press. 
Margono, S. 2010. Metodologi Penelitian

Pendidikan. Jakarta: Rineka Cipta.Jurusan Pendidikan Bahasa Jerman, FBS UNY.

Nunan, David. 1991. Language Teaching

Methodology: A Textbook for Teachers.

London: Prentice Hall.

Nurgiyantoro, Burhan., dkk. 2010. Penelitian

dalam Pengajaran Bahasa dan Sastra. Yogyakarta: BPFE.

Rayandra Asyar. (2012). Kreatif Mengembangkan Media Pembelajaran. Jakarta : Gaung Persada Pers

Sadiman, Arief S., dkk. 2007. Media Pendidikan: Pengertian, Pengembangan, dan Pemanfaatannya. Jakarta: PT Raja Grafindo Persada.
Sudjana, Nana (2004). -Dasar Proses Belajar Mengajar. Bandung : Sinar Baru Aglensindo Sugiyono. 2008. Statistika untuk Penelitian. Bandung: Alfabeta.

Sukamadinata. (2002). Metode Penelitian Pendidikan. Bandung : UPI dan PT. Remaja Rosdakarya

Sukardi, H.M. 2003. Metodologi Penelitian Pendidikan: Kompetensi dan Praktiknya. Jakarta: Bumi Aksara.

Tarigan, H.G. (1999). Menyimak Sebagai Suatu Ketrampilan Berbahasa. Bandung Angkas 